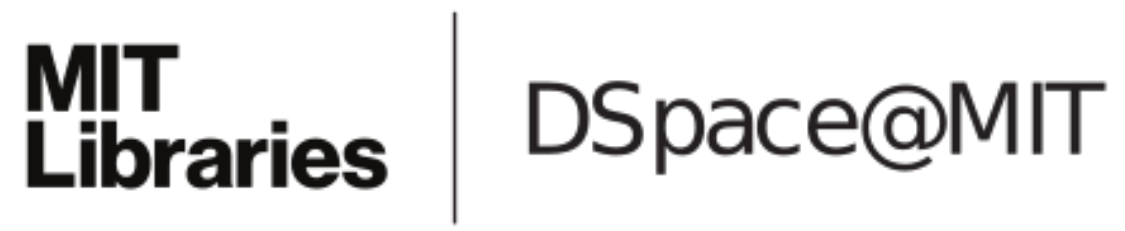

\author{
MIT Open Access Articles
}

Hotspot swells and the lifespan of volcanic ocean islands

The MIT Faculty has made this article openly available. Please share how this access benefits you. Your story matters.

Citation: Huppert, Kimberly L. et al. "Hotspot swells and the lifespan of volcanic ocean islands." Science Advances 6, 1 (January 2020): eaaw6906 (c) 2020 The Authors

As Published: http://dx.doi.org/10.1126/sciadv.aaw6906

Publisher: American Association for the Advancement of Science (AAAS)

Persistent URL: https://hdl.handle.net/1721.1/124017

Version: Final published version: final published article, as it appeared in a journal, conference proceedings, or other formally published context

Terms of use: Creative Commons Attribution NonCommercial License 4.0 


\section{Hotspot swells and the lifespan of volcanic ocean islands}

\author{
Kimberly L. Huppert ${ }^{1,2 *}$, J. Taylor Perron ${ }^{1}$, Leigh H. Royden ${ }^{1}$
}

\begin{abstract}
Volcanic ocean islands generally form on swells-seafloor that is shallower than expected for its age over areas hundreds to more than a thousand kilometers wide-and ultimately subside to form atolls and guyots (flattopped seamounts). The mechanisms of island drowning remain enigmatic, however, and the subaerial lifespan of volcanic islands varies widely. We examine swell bathymetry and island drowning at 14 hotspots and find a correspondence between island lifespan and residence time atop swell bathymetry, implying that islands drown as tectonic plate motion transports them past mantle sources of swell uplift. This correspondence argues strongly for dynamic uplift of the lithosphere at ocean hotspots. Our results also explain global variations in island lifespan, which influence island topography, biodiversity, and climate.
\end{abstract}

\section{INTRODUCTION}

The length of time volcanic islands stay above sea level strongly affects the evolution of their landscapes and biota (1), but island lifespans vary widely. Drowned islands in the Galápagos are as young as $\sim 6$ million years (Ma) old (2), whereas islands $>20$ Ma old persist above sea level in the Canary Islands. Island lifetime depends on the rate and magnitude of island subsidence, which, in turn, depends on the dynamics of the oceanic lithosphere and the underlying mantle. Ocean island lifetimes may therefore hold the key to resolving a conundrum about the mechanisms that modify seafloor depth at ocean hotspots.

Conductive cooling of the oceanic lithosphere is, in general, the first-order control on global seafloor depth (3), but the predictable pattern of seafloor deepening as it ages and moves away from midocean ridges goes awry at ocean hotspots, where the seafloor is anomalously shallow over broad regions. The processes generating these bathymetric swells are uncertain. Two end-member models (Fig. 1) have been proposed to explain swell uplift-each capable of reproducing some observations at ocean hotspots. The first model, lithospheric thinning (Fig. 1A), posits that reheating of the lithosphere, perhaps by vigorous secondary convection $(4,5)$, causes the seafloor to uplift due to the isostatic effect of replacing colder, denser lithosphere with hotter, less dense upper mantle (6). This thermal rejuvenation of the lithosphere could potentially explain the rapid uplift observed at ocean hotspots, provided that mantle temperatures are hot enough or mantle viscosity is sufficiently temperature-dependent to initiate convective instabilities that rapidly remove lithospheric material $(4,5)$. The lithospheric thinning model is also consistent with observed gravity anomalies [which indicate a source of compensation within the lithosphere $(7,8)$ ], magmatism, surface heat flow anomalies (9), and reductions in the effective elastic thickness of the lithosphere $(10,11)$ along some hotspot swells.

The second model, dynamic uplift (Fig. 1B), proposes that swells are supported by upward flow of ascending mantle plumes and/or hot, buoyant plume material ponded beneath the swell lithosphere $(5,12)$. The dynamic pressure created by active upwelling and in-

\footnotetext{
'Department of Earth, Atmospheric, and Planetary Sciences, Massachusetts Institute of Technology, Cambridge, MA 02139, USA. ${ }^{2}$ GFZ German Research Centre for Geosciences, Earth Surface Process Modelling, 14473 Potsdam, Germany.

*Corresponding author. Email: khuppert@gfz-potsdam.de
}

creased thermal buoyancy beneath the swell should produce broadly distributed surface uplift, consistent with observed swell morphology $(5,12)$. Unlike the lithospheric thinning model, the dynamic uplift model does not require reheating of the lithosphere. Thus, dynamic uplift may explain measurements showing no systematic variations in heat flow across some hotspot swells at their subsiding end (13) [provided that these measurements are not unduly biased by hydrothermal circulation (14)].

Seismic imaging may provide a direct test of these two uplift mechanisms, because thermal rejuvenation implies that the lithosphere should be substantially thinner beneath hotspot swells than beneath adjacent regions. However, the lithosphere-asthenosphere boundary (LAB) has only been imaged beneath confined regions of the Hawaiian (12), Cape Verde (15), and Galápagos (16) swells. Within these regions, arrivals of $S$-to- $P$ or $P$-to- $S$ waves suggest little or no lithospheric thinning or thinning within only a narrow region of the broader hotspot swell (assuming that seismic waves are indeed reflected at the LAB rather than at intralithospheric melt layers) $(12,15,16)$. At other hotspots, or even beyond the confined range of imaging at these well-studied hotspots, it remains unclear what role lithospheric thinning and dynamic uplift play in generating swells.

These two models also predict different patterns of seafloor subsidence following swell uplift. If swells are dominantly produced by lithospheric thinning and heating, then seafloor subsidence is the result of conductive cooling and contraction of reheated lithosphere. Despite some differences in the shape of the initial geotherm, the resulting thermal subsidence should approximately mimic the subsidence of much younger oceanic lithosphere. This places an upper bound on the rate of thermal subsidence that can be achieved following swell uplift, as conductive cooling of the lithosphere is a slow, gradual process. However, if swell topography is dominantly produced by dynamic uplift, then seafloor subsidence depends on how rapidly plate motion carries the seafloor off the swell, the spatial extent of the swell, and fluctuations in dynamic pressure beneath the swell.

Swell morphology and changes in island bathymetry through time may reveal which of these mechanisms dominates the process of swell uplift (although they may, and probably do, occur together to some extent). This requires a record of seafloor uplift and subsidence through time, such as that provided by paleoshorelines on 
island, atoll, and guyot volcanoes. In this study, we use the evolution of island volcanoes formed atop swells to infer the primary mechanism of swell compensation.

\section{RESULTS}

We analyzed swell morphology and the record of island drowning at 14 ocean hotspots (Fig. 2B). We used an objective filtering method (17) to isolate swell bathymetry at each hotspot (see Materials and Methods; Fig. 2, A and C; and fig. S2). We then compared the morphology of the swell tail at each hotspot to the expected subsidence

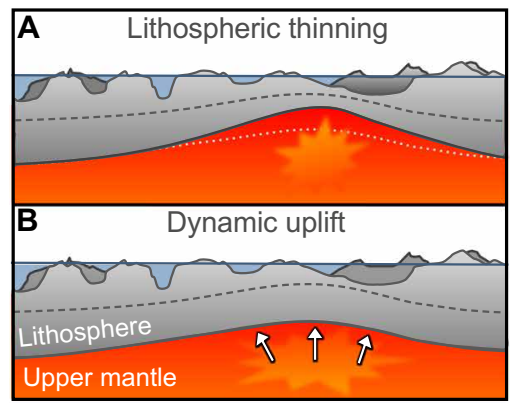

Fig. 1. Hypothesized mechanisms of swell uplift. (A) Lithospheric thinning or thermal rejuvenation of the lithosphere. Dotted white line shows initial lithospheric thickness before thinning. (B) Dynamic uplift. Dashed gray lines show seafloor depth in the absence of surface loading and associated flexural isostasy. Figure components are not to scale. of thermally rejuvenated lithosphere (Fig. 2, D and E, and fig. S2). We assumed that the lithosphere is reset to the thermal age required to explain the observed uplift -8 to $150 \mathrm{Ma}$ younger than the age of the seafloor-at the onset of each swell tail (table S1). At each hotspot, subsidence of the observed regional bathymetry outpaces the thermal subsidence of rejuvenated lithosphere (fig. S2). The difference is less pronounced at the Comoros (fig. $\mathrm{S} 2 \mathrm{H}$ ), Madeira (fig. S2L), and St. Helena (fig. S2O) hotspots, but the large discrepancies elsewhere suggest that the observed rates of subsidence are too rapid to be produced by conductive cooling of the lithosphere. This indicates that there must be a substantial component of dynamic (sublithospheric) compensation for the swells (table S4). This conclusion is valid regardless of whether the rapid subsidence is produced by fluctuations in dynamic compensation or from the volcanic islands being carried off the swell by plate motion. This result is also consistent with drill cores and seismic surveys of coral reef caps and the depths of wave-cut guyot terraces, which indicate that, following submergence, island volcanoes also subside substantially faster than predicted for normal conductive cooling of the lithosphere (Fig. 3) $(18,19)$.

If swells are generated by dynamic uplift (Fig. 1B), then the rates at which islands and the lithosphere are transported away from hotspots by plate motion should influence the rates and timing of island subsidence, provided that mantle buoyancy remains steady and the relevant density anomalies occur below the asthenosphere. Numerical models of plume-plate interactions develop time-invariant swell topography through either the formation of a steady plume train or steady shear-aligned flow (5). In these cases, the subaerial
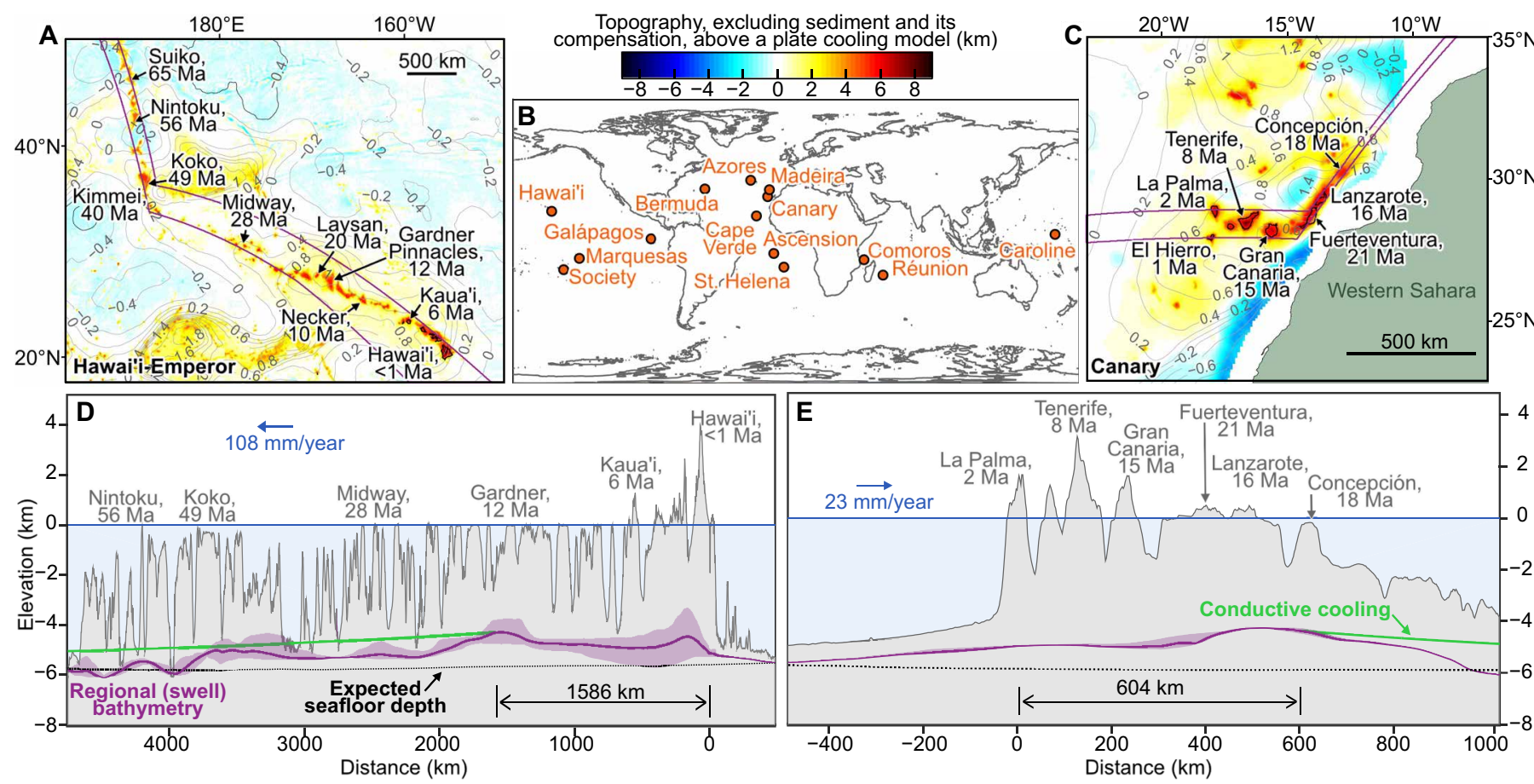

Fig. 2. Hotspot swells compared to subsidence of thermally rejuvenated lithosphere. (A and C) Anomalous bathymetry at Hawai'i and Canary hotspots, with contours showing regional (swell) bathymetry [km relative to a plate cooling model (3)]. Purple lines bound a swath profile along the azimuth of plate motion through all volcanoes, taking into account bends in each track. Only select volcanoes are labeled. (D and E) Gray silhouette shows maximum elevations along the profile. Purple line shows mean swell elevation, with shading spanning the range observed along the profile. Dotted line shows expected seafloor depth predicted by the plate cooling model. Green line shows modeled thermal subsidence of the lithosphere. Maps and profiles for all 14 hotspots analyzed (B) for two different plate cooling models are provided in fig. S2. 


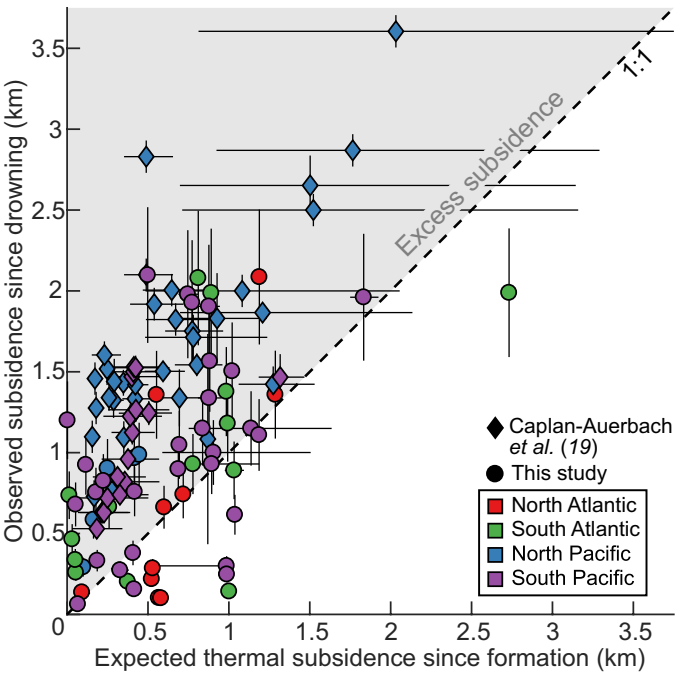

Fig. 3. Excess island subsidence following submergence. Expected thermal subsidence of seafloor underlying island volcanoes since volcano formation, based on radiometric seafloor (39) and volcano ages (table S3) (19) and a plate cooling model (3), versus observed, noncoral and/or sediment loading-related volcano subsidence since submergence below sea level, based on the depths of guyot tops and/or the thickness of coral reef caps (19). The isostatic effect of coral and/or sediment loading has been removed from the observed subsidence since drowning after (19), conservatively assuming Airy isostasy and coral/sediment thicknesses reported in (19) or extracted from a global sediment thickness map (21). Error bars reflect volcano age uncertainty and uncertainty associated with thickness of coral or sediment. Dashed line shows the 1:1 correspondence, $n=109$.

lifespan of ocean islands should relate to their residence time atop swell bathymetry, $\tau_{\mathrm{s}}$

$$
\tau_{\mathrm{s}} \sim \frac{\lambda_{\mathrm{s}}}{u_{\mathrm{p}}}
$$

where $\lambda_{s}$ is the distance from the hotspot to the subsiding swell tail in the direction of plate motion, and $u_{\mathrm{p}}$ is plate velocity. The correspondence between swell residence time and island lifespan may be particularly strong if swells are flat-topped with steep convex boundaries, as we observe (Fig. 2, D and E) and as expected for flexure of the lithosphere due to an impinging plume head (20).

To test this prediction, we estimated swell residence time $\tau_{\mathrm{s}}$ at each hotspot from measurements of swell length $\lambda_{\mathrm{s}}$ and plate velocity $u_{\mathrm{p}}$ (Eq. 1 and table S1). We found bimodally distributed $\tau_{\mathrm{s}}$, with short $\tau_{\mathrm{s}}$ clustered around $\sim 10 \mathrm{Ma}$ associated primarily with hotspots on fast-moving plates and longer $\tau_{\mathrm{s}}$ clustered around $\sim 25 \mathrm{Ma}$ associated primarily with hotspots on slower-moving plates. To compare these to the subaerial lifespan of islands in each hotspot chain, we bracketed the typical age of island drowning using the ages of volcanoes currently exposed above sea level as a lower bound and the ages of submerged volcanoes that show evidence of past subaerial eruption and erosion as an upper bound (tables S1 and S3). Evidence of past subaerial exposure includes wave-cut terraces, drowned coral, rounded cobbles and beach deposits, and vesicular or low-sulfur content basalt.

Swell residence time agrees well with the lifespan of islands in each chain (Fig. 4). Despite considerable differences in initial volcano elevations and the climatic settings of the various island chains [which affect the efficiency of their fluvial and coastal erosion (21) and their coral growth potential], island peak elevations decay to sea level or

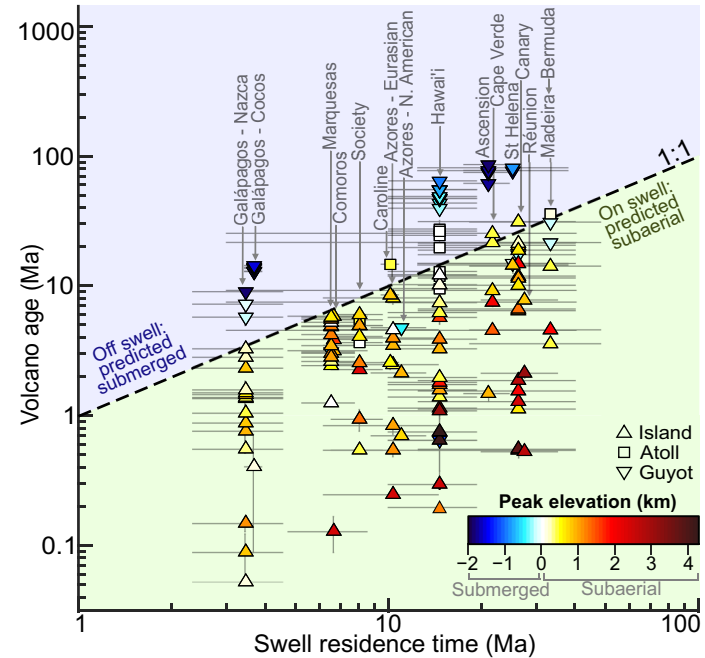

Fig. 4. Swell residence time and the lifespan of hotspot islands. Each column of data points corresponds to a hotspot island chain (labeled), plotted at the swell residence time given by dividing swell length by plate velocity. Island, atoll, and guyot volcano ages $(n=143)$ bracket the age of island drowning in each chain. Error bars reflect uncertainty in swell residence time due to uncertainty in plate velocity relative to the hotspot and uncertainty in the radiometric ages of volcanoes (table S3). Dashed line shows the 1:1 correspondence.

persist there with reef growth over the time period implied by swell length and plate motion with remarkable reliability. Only the North American Azores track appears to have an island lifespan that does not coincide with swell residence time when uncertainties in swell residence time and volcano ages are taken into account (22). Otherwise, the consistency between swell residence time and island lifespan supports the hypothesis that volcanic ocean islands generally drown when they migrate off swell bathymetry. This correlation also suggests that fluctuations in the dynamic support of the swell are probably not the dominant cause of island drowning, although exceptions may occur at individual swells.

This result indicates that there is an important sublithospheric source of swell compensation, because volcanoes migrate with the lithosphere as tectonic plates move relative to mantle buoyancy. If swell uplift primarily resulted from thermal rejuvenation of the lithosphere, then rates of seafloor and island subsidence would depend on the extent of thermal rejuvenation, and one would expect more gradual subsidence of islands on fast-moving plates that spend little time reheating over hotspot thermal anomalies (23). Our dataset shows exactly the opposite trend. Considering swell tail slopes and plate velocities, we find faster average swell subsidence rates (the product of swell tail slope and $\left.u_{p}\right)$ on the fast-moving Pacific Plate $(0.37 \mathrm{~mm} /$ year $)$ than on the slow-moving African Plate $(0.07 \mathrm{~mm} /$ year) (table S1).

\section{DISCUSSION}

Why has the correspondence between island lifespan and swell residence time gone unnoticed? Few studies (24) have used swell morphology to assess mechanisms of swell uplift because volcanic and sediment loads and variations in seafloor depth make it difficult to observe swell topography directly. We account for sediment loading explicitly and use an objective method to isolate swell bathymetry (17). Previous studies that have measured swell wavelength have focused on swell width perpendicular to plate motion to estimate 
hotspot buoyancy fluxes $(25,26)$, whereas we measured swell length parallel to plate motion to uncover the correlation. Consequently, patterns of swell subsidence have not been examined directly, although different swell compensation mechanisms should produce distinct patterns of swell subsidence.

Swell-controlled island subsidence may help explain the Darwin Point of atoll formation in the Hawaii-Emperor chain, the $\sim 24^{\circ}$ to $30^{\circ} \mathrm{N}$ zone of atoll drowning ( since $\geq 34 \mathrm{Ma}$ ) beyond which decreasing annual daylight, sea surface temperatures, and nutrient availability are thought to limit coral reef growth beyond a threshold for continued atoll development (27). Our analyses indicate that the Hawaiian Swell subsides within this latitude range, so we posit that relative sea level rise from atoll migration off the Hawaiian Swell also plays a central role in atoll drowning. Other hotspot island chains may have similar Darwin Points set by climate and geodynamic conditions.

Rapid subsidence as islands migrate away from a mantle source of swell uplift may also resolve the paradox of carbonate platform drowning. Drowned carbonate platforms are puzzlingly common, given that growth rates of healthy coral are much faster than typical rates of sea level rise. Rapid pulses of sea level rise, paleoenvironmental changes in equatorial regions, and other anomalous conditions have been proposed to explain the existence of drowned platforms $(28,29)$. Our results indicate that these explanations are unnecessary: Carbonate platforms that form on swells may drown when plate motion carries them away, since reefs subjected to normal environmental variability grow at unsteady rates that, over million-year time scales, will cumulatively fail to keep pace with sustained sea level rise that is more rapid than thermal subsidence (30).

Last, our results explain global variations in island lifespan, which influence island biodiversity and global climate. Models of island biogeography predict humped trends in carrying capacity, species richness, and speciation rates over the course of island landscape development, implying variations in biodiversity with island lifespan. Taking observed differences in island lifespan into account, these models predict global variations in island biodiversity, consistent with measurements of native species richness and singleisland endemism in the Azores, Canary, Galápagos, Marquesas, and Hawaiian islands (1). Our results demonstrate a geodynamic and tectonic control on island lifespan that implies clear links between island biodiversity and solid earth dynamics in different geographic settings-suggesting a geophysical mechanism underlying observed global variations in island biodiversity. Moreover, because drowned islands have served as source areas for the adaptive radiation of fauna inhabiting younger islands $(2,31,32)$ and have provided "stepping stones" and havens for the transoceanic dispersal of organisms, our results provide geodynamic and tectonic constraints on the duration of subaerial or shallow water volcano exposure that may be critical for understanding variations in biotic dispersal across different ocean basins (33).

Variations in island lifespan affect global climate by influencing biogeochemical cycles and patterns of oceanic and atmospheric circulation. Island lifespan controls the exposure of volcanic flows to chemical weathering, which may affect global consumption of atmospheric carbon dioxide by silicate weathering $(34,35)$. Island emergence and submergence can also affect the carbon cycle and global climate by perturbing ocean circulation, increasing phytoplankton productivity and carbon dioxide uptake in the lee of islands and in interisland channels (36) and potentially altering the period of El Niño Southern Oscillation through its impact on ocean-atmosphere heat exchange (37). Our observation that island lifespan is predominantly set by geodynamic and plate tectonic processes, rather than by island exposure to rainfall, waves, and other climatic drivers of erosion, has implications for quantifying the magnitude of island influences on global climate and for understanding feedbacks between global climate and the solid earth. Our results explain variations in island lifespan in different tectonic settings, which affect topography, biodiversity, and climate, and thereby link the evolution of the solid earth, biosphere, and hydrosphere.

\section{MATERIALS AND METHODS Experimental design}

We performed two analyses to assess the relative contribution of lithosphere and mantle processes to swell uplift and island subsidence. First, we compared the morphology of the subsiding swell tail at each hotspot to predicted thermal subsidence of reheated lithosphere. Second, we calculated the residence time of a volcano on each hotspot swell using measurements of swell length and plate velocity in the hotspot reference frame. We then compared swell residence times to the typical subaerial lifespan of islands, bracketed by the ages of the oldest subaerial and youngest submerged volcanoes in each chain. Both analyses used swell topography, which we isolated from the bathymetry by removing sediment loading and using an objective filtering method. The first analysis provides a test of the thermal rejuvenation hypothesis, while the second provides a test of swell compensation in the mantle, since a correspondence between the timing of island subsidence and plate tectonic motion supports a model in which island volcanoes and the lithosphere move past a mantle source of swell uplift.

\section{Isolating swell bathymetry}

We computed residual bathymetry relative to a plate cooling model (3) using ETOPO1 1 Arc-Minute Global Relief Model bathymetry (38) and seafloor ages interpolated between seafloor isochrons in the direction of seafloor spreading (39). We removed sediment and its flexural isostatic compensation based on a global sediment thickness map (40), the median estimated effective elastic thickness of the lithosphere at each hotspot (table S2) (41), a sediment density of $2300 \mathrm{~kg} / \mathrm{m}^{3}$, a water density of $1000 \mathrm{~kg} / \mathrm{m}^{3}$, an upper mantle density of $3330 \mathrm{~kg} / \mathrm{m}^{3}$, a Young's modulus of $10^{11} \mathrm{~Pa}$, and a Poisson ratio of 0.25 . We discretized sediment as gridded point loads to determine the pattern of deflection resulting from sediment loading. The effect of removing sediment and its compensation is minimal at intraplate hotspots, where sediment is nearly uniformly distributed and relatively thin. However, on passive margins, sediment thickness is spatially variable and can exceed $10 \mathrm{~km}$, so it can obscure evidence of swell topography (42).

We filtered the sediment-free residual bathymetry using a median filter, which returns the median value of pixels within a moving window. We used the optimal robust separator (ORS) filter width at each hotspot (table S2). The ORS filter width maximizes the mean amplitude of the short-wavelength bathymetry within a region bounded by a small positive contour (17). We used the 100 -m contour at hotspots on seafloor younger than $100 \mathrm{Ma}$ and the 200 -m contour at hotspots on older seafloor to avoid extraneous meandering of this contour in the presence of noise. We assumed that the ORS spatial median-filtered regional bathymetry represents swell bathymetry at each hotspot. 
The filtering method we used is designed to optimize the partitioning of short- and long-wavelength features of the bathymetry, which we expect relate uniquely to volcanic loading and swell uplift. However, if these processes act over similar spatial scales, the regional bathymetry we isolate might be biased by the presence of large volcanic surface loads. A particular concern is broad regions of thickened oceanic crust. Unfortunately, the depth of the Mohorovičic discontinuity has only been determined in a few hotspot island locations, so we lack sufficient information to account for crustal thickening in our calculations. Crustal thickening could produce shallow bathymetry surrounding ocean hotspots (43), but the onset of seafloor shallowing is typically hundreds of kilometers upstream of hotspot volcanism, and the existence of drowned island volcanoes in many hotspot chains argues against crustal thickening as the primary cause for shallow bathymetry. Isostasy calculations show that crustal thickening is insufficient to explain shallow seafloor depths near the Galápagos hotspot (44). The correspondence between filtered swell bathymetry and broad, coherent regions of shallow bathymetry visible in our unfiltered maps of anomalous seafloor depth suggests that the swell bathymetry we extract is not an artifact of our filtering technique. The frequent occurrence of volcanoes atop "normal" or even anomalously deep seafloor also suggests effective separation of short- and long-wavelength features (fig. S2). Swell uplift associated with oceanic hotspots is a robust feature of the bathymetry, analogously expressed in gravity anomaly data and seismic observations.

\section{Swell residence times}

We compiled radiometric ages of volcanoes and used the age-distance relationship of volcanoes $>1$ Ma to determine the azimuth and velocity of plate motion relative to the hotspot over the duration of volcanism in each chain (table S3). We assumed that the location of the hotspot coincides with the location of active volcanism, or we extrapolated to the position of the hotspot using the ages and locations of the youngest volcanoes and modeled globally consistent azimuths and velocities of plate motion over the past $5 \mathrm{Ma}(45)$ in chains without active volcanoes. We found separate azimuths of plate motion upstream and downstream of the bend in the Canary (46) and Hawaii-Emperor chain (47) and accounted for the change in hotspot or plate motion in our plate velocity calculation. We extracted a swath profile along the azimuth of plate motion through all volcanoes at each hotspot included in our compilation (fig. S2). We then measured the distance $\lambda_{s}$ along each profile from the hotspot to the point of maximum convexity of the swell (Laplacian of the swath profile mean regional bathymetry; solid purple lines in Fig. 2, D and E, and fig. S2), defining the upstream edge of the subsiding swell tail. Our results are relatively insensitive to this definition of $\lambda_{s}$ (figs. S3 to S6).

We divided $\lambda_{\mathrm{s}}$ by plate velocity $u_{\mathrm{p}}$ to calculate swell residence time, accounting for uncertainty in plate velocity using the SD of plate velocities associated with each volcano (table S1). The $u_{\mathrm{p}}$ values we calculated reflect the average rates of plate velocity relative to the hotspot over the duration of volcanism in each chain $(\sim 6$ to $>85 \mathrm{Ma})$. All but one of our estimates are within $10 \mathrm{~mm} /$ year of modeled globally consistent plate velocities averaged over the past $5 \mathrm{Ma}$ (45). The small differences-our estimates tend to be faster than the modeled ratesmay be partly due to hotspot motion. Paleomagnetic data indicate largely coherent hotspot motion over the past $40 \mathrm{Ma}$ in the direction opposite plate motion at hotspots on the Pacific Plate (48). Our estimates may also be biased slightly fast fast due to the tendency for volcanism to continue over a period following passage of the hotspot (45). We accounted for uncertainty in our $u_{\mathrm{p}}$ estimates by taking the SD of plate velocities implied by the age-distance relationship of all volcanoes to the hotspot (table S3).

Fractional uncertainties in plate velocity are $>45 \%$ at hotspots on the African plate-Cape Verde, Canary, St. Helena, and Madeira. These uncertainties reflect deviations from linear, age-progressive volcanism in each track. They may also reflect variations in plate motion. Our $u_{\mathrm{p}}$ estimates average over proposed changes in the direction and velocity of African plate motion [possible $33 \%$ deceleration in plate motion since 19 to $30 \mathrm{Ma}(49)$ ], Eurasian plate motion [possible change in azimuth within the past $\sim 3 \mathrm{Ma}(50)$ ], North American plate motion [possible deceleration 25 to $40 \mathrm{Ma}$ (51)], Pacific plate motion [possible changes in azimuth $\sim 6 \mathrm{Ma}$ (45) and in azimuth and velocity of plate motion $\sim 43$ to $48 \mathrm{Ma}$ (52)], and South American plate motion [possible increase in velocity from $\sim 20$ to $28 \mathrm{~mm} /$ year over the past $30 \mathrm{Ma}$ and transition from less northerly to more westerly motion (53)]. This may be a source of mismatch in our comparisons between swell residence time and island lifespan.

\section{Thermal rejuvenation of the lithosphere}

We used the swath profile mean regional seafloor depth, a plate cooling model, and parameters after (3) and (54) to determine the thermal reset age at each hotspot swell edge $\lambda_{\mathrm{s}}$ (table S1). We assume that the lithosphere has been thermally rejuvenated to this age, and we modeled thermal subsidence downstream of $\lambda_{\mathrm{s}}$ along the swath profile assuming that the seafloor ages with distance from $\lambda_{\mathrm{s}}$ based on the rate of plate velocity relative to the hotspot $u_{p}$. Predicted thermal subsidence of reheated lithosphere is virtually indistinguishable for the two plate cooling models, or it differs by $\leq \sim 10 \%$ compared to observed seafloor subsidence at each hotspot (fig. S2).

\section{Thermal rejuvenation of the lithosphere at the Galápagos hotspot}

To model swell subsidence along the Cocos and Nazca tracks of the Galápagos hotspot, where regional bathymetry is elevated above typical mid-ocean ridge depths, we computed the temperature profile of the lithosphere based on seafloor age at the swell tail

$$
T(z)=T_{m} \operatorname{erf}\left(\frac{z}{\sqrt{4 \kappa t}}\right)
$$

using upper mantle temperature $T_{m}=1450^{\circ} \mathrm{C}$ or $T_{m}=1350^{\circ} \mathrm{C}$, thermal diffusivity $\kappa=8.05 \times 10^{-7} \mathrm{~m}^{2} / \mathrm{s}$, and asymptotic plate thickness $L=95 \mathrm{~km}$ or $L=125 \mathrm{~m}$ after (3) and (54), respectively. We then found the depth of the $1000^{\circ}$ or $1250^{\circ} \mathrm{C}$ isotherm and set the temperature below the isotherm to the upper mantle temperature plus the thermal anomaly $\Delta T$ required to produce the observed seafloor depth, prescribed by

$$
d=d_{\mathrm{r}}+\frac{\rho_{\mathrm{m}} \alpha}{\rho_{\mathrm{m}}-\rho_{\mathrm{w}}} \int_{0}^{L}\left[T_{\mathrm{m}}-T(z)\right] \mathrm{dz}
$$

where $d_{\mathrm{r}}=2600 \mathrm{~m}$ or $d_{\mathrm{r}}=2500 \mathrm{~m}$ is mid-ocean ridge depth, $\rho_{\mathrm{m}}=3330 \mathrm{~kg} / \mathrm{m}^{3}$ and $\rho_{\mathrm{w}}=1000 \mathrm{~kg} / \mathrm{m}^{3}$ are upper mantle and water density, respectively, and $\alpha=3.1 \times 10^{-5}{ }^{\circ} \mathrm{C}^{-1}$ or $\alpha=3.28 \times 10^{-5}{ }^{\circ} \mathrm{C}^{-1}$ is the coefficient of thermal expansion. This approach is analogous to (19), and it assumes that the thinned lithosphere and underlying 
hot mantle layer are in isostatic equilibrium with a compensation depth of $L$. We used a fast Fourier transform method to forward model the thermal evolution of the lithosphere numerically, assuming that the seafloor ages at the rate of plate velocity and that the top and the base of the lithosphere are fixed at $0^{\circ} \mathrm{C}$ and $T_{m}+\Delta T$, respectively (55).

\section{SUPPLEMENTARY MATERIALS}

Supplementary material for this article is available at http://advances.sciencemag.org/cgi/ content/full/6/1/eaaw6906/DC1

Fig. S1. Hypothesized mechanisms of island drowning.

Fig. S2. Swell bathymetry and subsidence of thermally rejuvenated lithosphere at each hotspot.

Fig. S3. Swell subsidence versus subsidence of thermally rejuvenated lithosphere from the point of maximum convexity in swell amplitude.

Fig. S4. Swell residence time versus island lifespan, using a swell length set by the point of maximum convexity in swell amplitude at each hotspot.

Fig. S5. Swell subsidence versus subsidence of thermally rejuvenated lithosphere from the last downstream point of increase in swell amplitude at each hotspot.

Fig. S6. Swell residence time versus island lifespan, using a swell length set by the last downstream point of increase in swell amplitude at each hotspot.

Table S1. Thermal reset age, swell residence time, swell subsidence rate, and island lifespan. Table S2. Attributes for extracting swell bathymetry at each hotspot.

Table S3. Island, atoll, and guyot ages and plate motion relative to each hotspot.

Table S4. Maximum fraction of swell subsidence attributable to thermal subsidence. References (56-133)

\section{REFERENCES AND NOTES}

1. R. J. Whittaker, K. A. Triantis, R. J. Ladle, ORIGINAL ARTICLE: A general dynamic theory of oceanic island biogeography. J. Biogeogr. 35, 977-994 (2008).

2. D. Christie, R. A. Duncan, A. R. McBirney, M. A. Richards, W. M. White, K. S. Harpp, C. G. Fox, Drowned islands downstream from the Galapagos hotspot imply extended speciation times. Nature 355, 246-248 (1992).

3. C. A. Stein, S. Stein, A model for the global variation in oceanic depth and heat flow with lithospheric age. Nature 359, 123-129 (1992).

4. N. H. Sleep, Lithospheric thinning by midplate mantle plumes and the thermal history of hot plume material ponded at sublithospheric depths. J. Geophys. Res. Solid Earth 99, 9327-9343 (1994).

5. W. B. Moore, G. Schubert, P. Tackley, Three-dimensional simulations of plume-lithosphere interaction at the Hawaiian swell. Science 279, 1008-1011 (1998).

6. R. S. Detrick, S. T. Crough, Island subsidence, hot spots, and lithospheric thinning. J. Geophys. Res. Solid Earth 83, 1236-1244 (1978).

7. M. McNutt, Temperature beneath midplate swells: The inverse problem, in Seamounts, Islands, and Atolls, B. H. Keating, P. Fryer, R. Batiza, G. W. Boehlert, Eds. (American Geophysical Union, University of California, 1987), vol. 43, pp. 123-132.

8. J. Canales, J. Dañobeitia, The Canary Islands swell: A coherence analysis of bathymetry and gravity. Geophys. J. Int. 132, 479-488 (1998).

9. R. C. Courtney, R. S. White, Anomalous heat flow and geoid across the Cape Verde Rise: Evidence for dynamic support from a thermal plume in the mantle. Geophys. J. Int. 87, 815-867 (1986).

10. M. K. McNutt, Lithospheric flexure and thermal anomalies. J. Geophys. Res. Solid Earth 89, 11180-11194 (1984).

11. U. ten Brink, A. B. Watts, Seismic stratigraphy of the flexural moat flanking the Hawaiian Islands. Nature 317, 421-424 (1985).

12. X. Li, R. Kind, X. Yuan, I. Wölbern, W. Hanka, Rejuvenation of the lithosphere by the Hawaiian plume. Nature 427, 827-829 (2004).

13. R. Von Herzen, M. Cordery, R. Detrick, C. Fang, Heat flow and the thermal origin of hot spot swells: The Hawaiian swell revisited. J. Geophys. Res. Solid Earth 94, 13783-13799 (1989).

14. R. N. Harris, M. K. McNutt, Heat flow on hot spot swells: Evidence for fluid flow. J. Geophys. Res. Solid Earth 112, B03407 (2007).

15. A. Lodge, G. Helffrich, Depleted swell root beneath the Cape Verde Islands. Geology 34, 449-452 (2006).

16. C. A. Rychert, N. Harmon, C. Ebinger, Receiver function imaging of lithospheric structure and the onset of melting beneath the Galápagos Archipelago. Earth Planet. Sci. Lett. 388, 156-165 (2014).

17. P. Wessel, An empirical method for optimal robust regional-residual separation of geophysical data. Math. Geol. 30, 391-408 (1998).

18. H. Menard, Insular erosion, isostasy, and subsidence. Science 220, 913-918 (1983).
19. J. Caplan-Auerbach, F. Duennebier, G. Ito, Origin of intraplate volcanoes from guyot heights and oceanic paleodepth. J. Geophys. Res. Solid Earth 105, 2679-2697 (2000).

20. H. E. Huppert, The propagation of two-dimensional and axisymmetric viscous gravity currents over a rigid horizontal surface. J. Fluid Mech. 121, 43-58 (1982).

21. K. L. Ferrier, K. L. Huppert, J. T. Perron, Climatic control of bedrock river incision. Nature 496, 206-209 (2013)

22. Materials and methods are available as supplementary materials at the Science website.

23. M. McNutt, Thermal and mechanical properties of the Cape Verde Rise. J. Geophys. Res. Solid Earth 93, 2784-2794 (1988).

24. L. Sichoix, A. Bonneville, M. K. McNutt, The seafloor swells and Superswell in French Polynesia. J. Geophys. Res. Solid Earth 103, 27123-27133 (1998).

25. M. Monnereau, A. Cazenave, Depth and geoid anomalies over oceanic hotspot swells: A global survey. J. Geophys. Res. Solid Earth 95, 15429-15438 (1990).

26. S. D. King, C. Adam, Hotspot swells revisited. Phys. Earth Planet. In. 235, 66-83 (2014).

27. R. W. Grigg, Paleoceanography of coral reefs in the Hawaiian-Emperor Chain - revisited. Coral Reefs 16, S33-S38 (1997)

28. P. A. Wilson, H. C. Jenkyns, H. Elderfield, R. L. Larson, The paradox of drowned carbonate platforms and the origin of Cretaceous Pacific guyots. Nature 392, 889-894 (1998).

29. W. Schlager, The paradox of drowned reefs and carbonate platforms. Geol. Soc. Am. Bull. 92, 197-211 (1981).

30. W. Schlager, Scaling of sedimentation rates and drowning of reefs and carbonate platforms. Geology 27, 183-186 (1999).

31. J.-F. Butaud, F. Rives, D. Verhaegen, J.-M. Bouvet, Phylogeography of eastern Polynesian sandalwood (Santalum insulare), an endangered tree species from the Pacific: A study based on chloroplast microsatellites. J. Biogeogr. 32, 1763-1774 (2005).

32. J. P. Price, D. A. Clague, How old is the Hawaiian biota? Geology and phylogeny suggest recent divergence. Proc. Biol. Sci. 269, 2429-2435 (2002).

33. M. E. Johnson, B. G. Baarli, M. Cachão, E. Mayoral, R. S. Ramalho, A. Santos, C. M. da Silva, On the rise and fall of oceanic islands: Towards a global theory following the pioneering studies of Charles Darwin and James Dwight Dana. Earth Sci. Rev. 180, 17-36 (2018).

34. S. D. Rad, C. J. Allègre, P. Louvat, Hidden erosion on volcanic islands. Earth Planet. Sci. Lett. 262, 109-124 (2007).

35. C. Dessert, B. Dupré, J. Gaillardet, L. M. François, C. J. Allegre, Basalt weathering laws and the impact of basalt weathering on the global carbon cycle. Chem. Geol. 202, 257-273 (2003).

36. K. J. Heywood, E. D. Barton, J. H. Simpson, The effects of flow disturbance by an oceanic island. J. Mar. Res. 48, 55-73 (1990).

37. K. B. Karnauskas, R. Murtugudde, A. J. Busalacchi, The effect of the Galápagos Islands on ENSO in forced ocean and hybrid coupled models. J. Phys. Oceanogr. 38, 2519-2534 (2008).

38. C. Amante, ETOPO1 1 arc-minute global relief model: Procedures, data sources and analysis (2009); www.ngdc.noaa.gov/mgg/global/global.html.

39. R. D. Müller, M. Sdrolias, C. Gaina, W. R. Roest, Age, spreading rates, and spreading asymmetry of the world's ocean crust. Geochem. Geophys. Geosyst. 9, Q04006 (2008).

40. D. Divins, Total Sediment Thickness of the World's Oceans and Marginal Seas (NOAA, National Geophysical Data Center, Boulder, CO, 2003).

41. A. B. Watts, S. Zhong, Observations of flexure and the rheology of oceanic lithosphere Geophys. J. Int. 142, 855-875 (2000).

42. C. R. Ranero, M. Torne, E. Banda, Gravity and multichannel seismic reflection constraints on the lithospheric structure of the Canary Swell. Mar. Geophys. Res. 17, 519-534 (1995).

43. V. Sallarès, P. Charvis, Crustal thickness constraints on the geodynamic evolution of the Galapagos Volcanic Province. Earth Planet. Sci. Lett. 214, 545-559 (2003).

44. J. P. Canales, G. Ito, R. S. Detrick, J. Sinton, Crustal thickness along the western Galápagos Spreading Center and the compensation of the Galápagos hotspot swell. Earth Planet. Sci. Lett. 203, 311-327 (2002).

45. W. J. Morgan, J. P. Morgan, Plate velocities in the hotspot reference frame. Geol. Soc. Am. 430, 65 (2007).

46. J. C. Carracedo, S. Day, H. Guillou, E. Rodríguez Badiola, J. A. Canas, F. J. Pérez Torrado, Hotspot volcanism close to a passive continental margin: The Canary Islands. Geol. Mag. 135, 591-604 (1998).

47. E. Christofferson, in EOS (American Geophysical Union, 1968), vol. 49, p. 214.

48. B. Steinberger, R. J. O'Connell, Effects of mantle flow on hotspot motion. Hist. Dynam. Global Plate Motions 377-398 (2000).

49. J. M. O'Connor, P. Stoffers, P. van den Bogaard, M. McWilliams, First seamount age evidence for significantly slower African plate motion since 19 to 30 Ma. Earth Planet. Sci. Lett. 171, 575-589 (1999).

50. E. Calais, C. DeMets, J.-M. Nocquet, Evidence for a post-3.16-Ma change in Nubia-EurasiaNorth America plate motions? Earth Planet. Sci. Lett. 216, 81-92 (2003).

51. T. A. Cross, R. H. Pilger, Constraints on absolute motion and plate interaction inferred from Cenozoic igneous activity in the western United States. Am. J. Sci. 278, 865-902 (1978). 
52. W. D. Sharp, D. A. Clague, 50-Ma initiation of Hawaiian-Emperor bend records major change in Pacific plate motion. Science 313, 1281-1284 (2006).

53. P. G. Silver, R. M. Russo, C. Lithgow-Bertelloni, Coupling of South American and African plate motion and plate deformation. Science 279, 60-63 (1998).

54. B. Parsons, J. G. Sclater, An analysis of the variation of ocean floor bathymetry and heat flow with age. J. Geophys. Res. 82, 803-827 (1977).

55. D. H. Mugler, R. A. Scott, Fast fourier transform method for partial differential equations, case study: The 2-D diffusion equation. Comput. Mathematics Applications 16, 221-228 (1988).

56. K. L. Huppert, L. H. Royden, J. T. Perron, Dominant influence of volcanic loading on vertical motions of the Hawaiian Islands. Earth Planet. Sci. Lett. 418, 149-171 (2015).

57. H. Steffen, G. Kaufmann, Glacial isostatic adjustment of Scandinavia and northwestern Europe and the radial viscosity structure of the Earth's mantle. Geophys. J. Int. 163, 801-812 (2005).

58. D. Turcotte, G. Schubert, Geodynamics (Cambridge Univ. Press, 2018).

59. F. F. Pollitz, R. Bürgmann, B. Romanowicz, Viscosity of oceanic asthenosphere inferred from remote triggering of earthquakes. Science 280, 1245-1249 (1998).

60. A. Davaille, C. Jaupart, Onset of thermal convection in fluids with temperaturedependent viscosity: Application to the oceanic mantle. J. Geophys. Res. Solid Earth 99, 19853-19866 (1994).

61. S. Zhong, A. B. Watts, Constraints on the dynamics of mantle plumes from uplift of the Hawaiian Islands. Earth Planet. Sci. Lett. 203, 105-116 (2002).

62. A. B. Watts, Gravity and bathymetry in the central Pacific Ocean. J. Geophys. Res. 81, 1533-1553 (1976).

63. A. B. Watts, C. Peirce, J. Collier, R. Dalwood, J. P. Canales, T. J. Henstock, A seismic study of lithospheric flexure in the vicinity of Tenerife, Canary Islands. Earth Planet. Sci. Lett. 146, 431-447 (1997).

64. C. Harris, J. D. Bell, F. B. Atkins, Isotopic composition of lead and strontium in lavas and coarse-grained blocks from Ascension Island, South Atlantic. Earth Planet. Sci. Lett. 60, 79-85 (1982).

65. D. L. Nielson, B. S. Sibbett, Geology of Ascension Island, South Atlantic Ocean. Geothermics 25, 427-448 (1996).

66. N. Z. Cherkis, D. A. Chayes, L. C. Costa, The bathymetry and distribution of the Bahia Seamounts, Brazil Basin. Mar. Geol. 103, 335-347 (1992).

67. S. G. Skolotnev, M. E. Bylinskaya, L. A. Golovina, I. S. Ipat'eva, The origin of Bahia seamounts (Brazil Basin, South Atlantic) in connection to new data on their age, in Doklady Earth Sciences (Springer, 2012), vol. 443, pp. 444-450.

68. A. Hildenbrand, F. O. Marques, A. C. G. Costa, A. L. R. Sibrant, P. F. Silva, B. Henry, J. M. Miranda, P. Madureira, Reconstructing the architectural evolution of volcanic islands from combined K/Ar, morphologic, tectonic, and magnetic data: The Faial Island example (Azores). J. Volcanol. Geotherm. Res. 241, 39-48 (2012).

69. J. M. M. Azevedo, M. R. P. Ferreira, The volcanotectonic evolution of Flores Island, Azores (Portugal). J. Volcanol. Geotherm. Res. 156, 90-102 (2006).

70. G. Feraud, I. Kaneoka, C. J. Allègre, K/Ar ages and stress pattern in the Azores: Geodynamic implications. Earth Planet. Sci. Lett. 46, 275-286 (1980).

71. A. A. Abdel-Monem, L. A. Fernandez, G. M. Boone, K-Ar ages from the eastern Azores group (Santa Maria, São Miguel and the Formigas islands). Lithos 8, 247-254 (1975).

72. P. J. C. Ryall, M.-C. Blanchard, F. Medioli, A subsided island west of Flores, Azores. Can. J. Earth Sci. 20, 764-775 (1983)

73. P. H. Reynolds, F. Aumento, Deep Drill 1972. Potassium-Argon dating of the Bermuda drill core. Can. J. Earth Sci. 11, 1269-1273 (1974).

74. H. Guillou, J. C. Carracedo, F. P. Torrado, E. R. Badiola, K-Ar ages and magnetic stratigraphy of a hotspot-induced, fast grown oceanic island: El Hierro, Canary Islands. J. Volcanol. Geotherm. Res. 73, 141-155 (1996).

75. H. Staudigel, G. Feraud, G. Giannerini, The history of intrusive activity on the island of La Palma (Canary Islands). J. Volcanol. Geotherm. Res. 27, 299-322 (1986).

76. A. Abdel-Monem, N. D. Watkins, P. W. Gast, Potassium-argon ages, volcanic stratigraphy, and geomagnetic polarity history of the Canary Islands; Tenerife, La Palma and Hierro. Am. J. Sci. 272, 805-825 (1972).

77. A. Abdel-Monem, N. D. Watkins, P. W. Gast, Potassium-argon ages, volcanic stratigraphy, and geomagnetic polarity history of the Canary Islands; Lanzarote, Fuerteventura, Gran Canaria, and La Gomera. Am. J. Sci. 271, 490-521 (1971).

78. E. Ancochea, J. M. Fuster, E. Ibarrola, A. Cendrero, J. Coello, F. Hernan, J. M. Cantagrel, C. Jamond, Volcanic evolution of the island of Tenerife (Canary Islands) in the light of new K-Ar data. J. Volcanol. Geotherm. Res. 44, 231-249 (1990).

79. G. Féraud, G. Giannérini, R. Campredon, C. J. Stillman, Geochronology of some Canarian dike swarms: Contribution to the volcano-tectonic evolution of the archipelago. J. Volcanol. Geotherm. Res. 25, 29-52 (1985).

80. E. Ancochea, J. L. Brändle, C. Cubas, F. Hernán, M. J. Huertas, Volcanic complexes in the eastern ridge of the Canary Islands: The Miocene activity of the island of Fuerteventura. J. Volcanol. Geotherm. Res. 70, 183-204 (1996).

81. J. Coello, J.-M. Cantagrel, F. Hernán, J.-M. Fúster, E. Ibarrola, E. Ancochea, C. Casquet, C. Jamond, J.-R. Díaz de Téran, A. Cendrero, Evolution of the eastern volcanic ridge of the Canary Islands based on new K-Ar data. J. Volcanol. Geotherm. Res. 53, 251-274 (1992).

82. J. Geldmacher, K. Hoernle, P. van den Bogaard, G. Zankl, D. Garbe-Schönberg, Earlier history of the $\geq 70$-Ma-old Canary hotspot based on the temporal and geochemica evolution of the Selvagen Archipelago and neighboring seamounts in the eastern North Atlantic. J. Volcanol. Geotherm. Res. 111, 55-87 (2001).

83. S. Plesner, P. M. Holm, J. R. Wilson, ${ }^{40} \mathrm{Ar}-{ }^{39} \mathrm{Ar}$ geochronology of Santo Antão, Cape Verde Islands. J. Volcanol. Geotherm. Res. 120, 103-121 (2003).

84. P. M. Holm, T. Grandvuinet, J. Friis, J. R. Wilson, A. K. Barker, S. Plesner, $\mathrm{An}^{40} \mathrm{Ar}-{ }^{39} \mathrm{Ar}$ study of the Cape Verde hot spot: Temporal evolution in a semistationary plate environment. J. Geophys. Res. Solid Earth 113, B08201 (2008).

85. P. C. Torres, Geologia da llha do Sal (2002).

86. B. H. Keating, D. P. Mattey, C. E. Helsley, J. J. Naughton, D. Epp, A. Lazarewicz, D. Schwank, Evidence for a hot spot origin of the Caroline Islands. J. Geophys. Res. Solid Earth $\mathbf{8 9}$, 9937-9948 (1984).

87. C. M. Emerick, R. A. Duncan, Age progressive volcanism in the Comores Archipelago, western Indian Ocean and implications for Somali plate tectonics. Earth Planet. Sci. Lett. 60, 415-428 (1982)

88. J. Nougier, J. M. Cantagrel, J. P. Karche, The Comores archipelago in the western Indian Ocean: Volcanology, geochronology and geodynamic setting. J. African Earth Sci. (1983) 5, 135-145 (1986).

89. W. M. White, A. R. McBirney, R. A. Duncan, Petrology and geochemistry of the Galápagos Islands: Portrait of a pathological mantle plume. J. Geophys. Res. Solid Earth $\mathbf{9 8}$ 19533-19563 (1993).

90. R. Werner, K. Hoernle, P. van den Bogaard, C. Ranero, R. von Huene, D. Korich, Drowned 14-m.y.-old Galápagos archipelago off the coast of Costa Rica: Implications for tectonic and evolutionary models. Geology 27, 499-502 (1999).

91. R. K. Werner, K. Hoernle, New volcanological and volatile data provide strong support for the continuous existence of Galápagos Islands over the past 17 million years. Int. J. Earth Sci. 92, 904-911 (2003).

92. A. Cox, G. B. Dalrymple, Palaeomagnetism and potassium-argon ages of some volcanic rocks from the Galapagos Islands. Nature 209, 776-777 (1966).

93. F. J. Swanson, H. W. Baitis, J. Lexa, J. Dymond, Geology of Santiago, Rábida, and Pinzón Islands, Galápagos. Geol. Soc. Am. Bull. 85, 1803-1810 (1974).

94. K. Bailey, Potassium-argon ages from the Galápagos Islands. Science 192, 465-467 (1976).

95. J. G. Moore, D. A. Clague, Volcano growth and evolution of the island of Hawaii. Geol. Soc. Am. Bull. 104, 1471-1484 (1992).

96. M. O. Garcia, D. Hanano, A. Flinders, D. Weis, G. Ito, M. D. Kurz, Age, geology, geophysics, and geochemistry of Mahukona Volcano, Hawai i. Bull. Volcanol. 74, 1445-1463 (2012).

97. P. W. Lipman, J. M. Rhodes, G. B. Dalrymple, The Ninole Basalt-Implications for the structural evolution of Mauna Loa volcano, Hawaii. Bull. Volcanol. 53, 1-19 (1990).

98. W. D. Sharp, P. R. Renne, $\mathrm{The}{ }^{40} \mathrm{Ar} /{ }^{39} \mathrm{Ar}$ dating of core recovered by the Hawaii Scientific Drilling Project (phase 2), Hilo, Hawaii. Geochem. Geophys. Geosyst. 6, Q04G17 (2005).

99. P. W. Lipman, A. T. Calvert, Early growth of Kohala volcano and formation of long Hawaiian rift zones. Geology 39, 659-662 (2011).

100. C.-Y. Chen, F. A. Frey, M. O. Garcia, G. B. Dalrymple, S. R. Hart, The tholeiite to alkalic basalt transition at Haleakala Volcano, Maui, Hawaii. Contrib. Mineral. Petrol. 106, 183-200 (1991).

101. H. Sano, D. R. Sherrod, T. Tagami, Youngest volcanism about 1 million years ago at Kahoolawe Island, Hawaii. J. Volcanol. Geotherm. Res. 152, 91-96 (2006).

102. R. Leonhardt, M. McWilliams, F. Heider, H. C. Soffel, The Gilsá excursion and the Matuyama/Brunhes transition recorded in ${ }^{40} \mathrm{Ar} /{ }^{39} \mathrm{Ar}$ dated lavas from Lanai and Maui, Hawaiian Islands. Geophys. J. Int. 179, 43-58 (2009).

103. J. J. Naughton, G. A. Macdonald, V. A. Greenberg, Some additional potassium-argon ages of Hawaiian rocks: The Maui volcanic complex of Molokai, Maui, Lanai and Kahoolawe. J. Volcanol. Geotherm. Res. 7, 339-355 (1980).

104. D. R. Sherrod, T. Murai, T. Tagami, New K-Ar ages for calculating end-of-shield extrusion rates at West Maui volcano, Hawaiian island chain. Bull. Volcanol. 69, 627-642 (2007).

105. S. Yamasaki, R. Sawada, A. Ozawa, T. Tagami, Y. Watanabe, E. Takahashi, Unspiked K-Ar dating of Koolau lavas, Hawaii: Evaluation of the influence of weathering/alteration on age determinations. Chem. Geol. 287, 41-53 (2011).

106. H. Guillou, J. Sinton, C. Laj, C. Kissel, N. Szeremeta, New K-Ar ages of shield lavas from Waianae volcano, Oahu, Hawaiian archipelago. J. Volcanol. Geotherm. Res. 96, 229-242 (2000).

107. I. McDougall, Potassium-argon ages from lavas of the Hawaiian Islands. Geol. Soc. Am. Bull. 75, 107-128 (1964).

108. D. R. Sherrod, J. M. Sinton, S. E. Watkins, K. M. Brunt, Geologic map of the State of Hawai'i, US Geological Survey Open-File Report 2007-1089 (2007).

109. G. B. Dalrymple, M. A. Lanphere, E. D. Jackson, Contributions to the petrography and geochronology of volcanic rocks from the Leeward Hawaiian Islands. Geol. Soc. Am. Bull. 85, 727-738 (1974). 
110. M. O. Garcia, D. G. Grooms, J. J. Naughton, Petrology and geochronology of volcanic rocks from seamounts along and near the Hawaiian Ridge: Implications for propagation rate of the ridge. Lithos 20, 323-336 (1987).

111. G. B. Dalrymple, D. A. Clague, M. O. Garcia, S. W. Bright, Petrology and K-Ar ages of dredged samples from Laysan Island and Northampton Bank volcanoes, Hawaiian ridge, and evolution of the Hawaiian-Emperor chain. Geol. Soc. Am. Bull. 92, 884-933 (1981).

112. J. M. O'Connor, B. Steinberger, M. Regelous, A. A. P. Koppers, J. R. Wijbrans, K. M. Haase, P. Stoffers, W. Jokat, D. Garbe-Schönberg, Constraints on past plate and mantle motion from new ages for the Hawaiian-Emperor Seamount Chain. Geochem. Geophys. Geosyst. 14, 4564-4584 (2013).

113. N. C. Smoot, Guyot and seamount morphology and tectonics of the Hawaiian-Emperor elbow by multi-beam sonar. Mar. Geol. 64, 203-215 (1985).

114. T. A. Davies, P. Wilde, D. A. Clague, Kōko seamount: A major guyot at the southern end of the Emperor seamounts. Mar. Geol. 13, 311-321 (1972).

115. G. B. Dalrymple, D. A. Clague, Age of the Hawaiian-Emperor bend. Earth Planet. Sci. Lett. 31, 313-329 (1976)

116. R. A. Duncan, R. A. Keller, Radiometric ages for basement rocks from the Emperor Seamounts, ODP Leg 197. Geochem. Geophys. Geosyst. 5, Q08L03 (2004).

117. G. J. Dalrymple, Conventional and ${ }^{40} \mathrm{Ar} /{ }^{39} \mathrm{Ar} \mathrm{K}$-Ar ages of volcanic rocks from Ojin (Site 430), Nintoku (Site432) and Suiko (Site 433) seamounts and the chronology of volcanic propagation along the Hawaiian-Emperor chain. Initial Rep. Deep Sea Drill. Proj. 55, 659-676 (1980).

118. N. C. Smoot, Guyots of the Mid-Emperor Chain mapped with multibeam sonar. Mar. Geol. 47, 153-163 (1982)

119. G. B. Dalrymple, M. O. Garcia, Age and chemistry of volcanic rocks dredged from Jingu Seamount, Emperor Seamount chain. Initial Rep. Deep Sea Drill. Proj. 55, 685-693 (1980).

120. J. Geldmacher, P. van den Bogaard, K. Hoernle, H.-U. Schmincke, The ${ }^{40} \mathrm{Ar} /{ }^{39} \mathrm{Ar}$ age dating of the Madeira Archipelago and hotspot track (eastern North Atlantic). Geochem. Geophys. Geosyst. 1, (2000).

121. J. Geldmacher, K. Hoernle, P. Bogaard, S. Duggen, R. Werner, New ${ }^{40} \mathrm{Ar} /{ }^{39} \mathrm{Ar}$ age and geochemical data from seamounts in the Canary and Madeira volcanic provinces: Support for the mantle plume hypothesis. Earth Planet. Sci. Lett. 237, 85-101 (2005).

122. D. L. Desonie, R. A. Duncan, J. H. Natland, Temporal and geochemical variability of volcanic products of the Marquesas hotspot. J. Geophys. Res. Solid Earth 98, 17649-17665 (1993).

123. V. Clouard, A. Bonneville, Ages of seamounts, islands, and plateaus on the Pacific plate. Geol. Soc. Am. 388, 71 (2005)

124. P.-Y. Gillot, P. Nativel, Eruptive history of the Piton de la Fournaise volcano, Réunion island, Indian Ocean. J. Volcanol. Geotherm. Res. 36, 53-65 (1989).
125. A. K. Baksi, K. A. Hoffman, On the age and morphology of the Réunion event. Geophys. Res. Lett. 27, 2997-3000 (2000).

126. I. McDougall, F. H. Chamalaun, Isotopic dating and geomagnetic polarity studies on volcanic rocks from Mauritius, Indian Ocean. Geol. Soc. Am. Bull. 80, 1419-1442 (1969).

127. I. McDougall, W. Compston, Strontium isotope composition and potassium-rubidium ratios in some rocks from Réunion and Rodriguez, Indian Ocean. Nature 207, 252-253 (1965).

128. I. Baker, N. H. Gale, J. Simons, Geochronology of the St Helena volcanoes. Nature 215 , 1451-1456 (1967).

129. J. M. O'Connor, A. P. le Roex, South Atlantic hot spot-plume systems: 1 . Distribution of volcanism in time and space. Earth Planet. Sci. Lett. 113, 343-364 (1992).

130. I. Le Roy, thesis, Paris 11 (1994).

131. R. A. Duncan, M. R. Fisk, W. M. White, R. L. Nielsen, Tahiti: Geochemical evolution of a French Polynesian volcano. J. Geophys. Res. Solid Earth 99, 24341-24357 (1994).

132. H. Bellon, F. Blanchard, Aspects géochronologiques (K-Ar) de l'activité volcanique dans I'île de moorea, Pacifique Central. Tectonophysics. 72, T33-T43 (1981).

133. K. G. Miller, M. A. Kominz, J. V. Browning, J. D. Wright, G. S. Mountain, M. E. Katz, P. J. Sugarman, B. S. Cramer, N. Christie-Blick, S. F. Pekar, The Phanerozoic record of global sea-level change. Science 310, 1293-1298 (2005).

Acknowledgments: We thank R. Moucha, F. Richards, and two anonymous reviewers for insightful comments that improved the manuscript. Funding: This study was supported by the Massachusetts Institute of Technology, the NEC Corporation, and NASA Headquarters under the NASA Earth and Space Science Fellowship Program—grant NNX13AN67H. Author contributions: K.L.H. compiled the data, performed the bathymetric analyses and thermal modeling, and wrote the manuscript with input from the other authors. All authors contributed to the interpretation and discussion of the results. Competing interest: The authors declare that they have no competing interests. Data and materials availability: All data needed to evaluate the conclusions in the paper are present in the paper and/or the Supplementary Materials. Additional data related to this paper may be requested from the authors.

Submitted 16 January 2019

Accepted 24 October 2019

Published 1 January 2020

$10.1126 /$ sciadv.aaw6906

Citation: K. L. Huppert, J. T. Perron, L. H. Royden, Hotspot swells and the lifespan of volcanic ocean islands. Sci. Adv. 6, eaaw6906 (2020). 


\section{ScienceAdvances}

Hotspot swells and the lifespan of volcanic ocean islands

Kimberly L. Huppert, J. Taylor Perron and Leigh H. Royden

Sci Adv 6 (1), eaaw6906.

DOI: $10.1126 /$ sciadv.aaw6906

ARTICLE TOOLS

SUPPLEMENTARY

MATERIALS

REFERENCES

PERMISSIONS http://advances.sciencemag.org/content/6/1/eaaw6906

http://advances.sciencemag.org/content/suppl/2019/12/20/6.1.eaaw6906.DC1

This article cites 121 articles, 24 of which you can access for free http://advances.sciencemag.org/content/6/1/eaaw6906\#BIBL

http://www.sciencemag.org/help/reprints-and-permissions

Science Advances (ISSN 2375-2548) is published by the American Association for the Advancement of Science, 1200 New York Avenue NW, Washington, DC 20005. The title Science Advances is a registered trademark of AAAS.

Copyright (C) 2020 The Authors, some rights reserved; exclusive licensee American Association for the Advancement of Science. No claim to original U.S. Government Works. Distributed under a Creative Commons Attribution NonCommercial License 4.0 (CC BY-NC). 